\title{
ARTIFICIAL NEURAL NETWORK OPTIMIZATION MODELING ON ENGINE PERFORMANCE OF DIESEL ENGINE USING BIODIESEL FUEL
}

\author{
M.R. Shukri, M.M. Rahman, D. Ramasamy and K. Kadirgama
}

\author{
Faculty of Mechanical Engineering, \\ Universiti Malaysia Pahang \\ 26600 Pekan, Pahang, Malaysia \\ Email: mustafizur@ump.edu.my \\ Phone: +6094246239; Fax: +6094246222
}

\begin{abstract}
This paper presents a study of engine performance using a mixture of palm oil methyl ester blends with diesel oil as biodiesel in a diesel engine, and optimizes the engine performance using artificial neural network (ANN) modeling. To acquire data for training and testing of the proposed ANN, a four-cylinder, four-stroke diesel engine was fuelled with different palm oil methyl ester blends as biodiesel, operated at different engine loads. The properties of biodiesel produced from waste vegetable oil were measured based on ASTM standards. The experimental results revealed that blends of palm oil methyl ester with diesel fuel provided better engine performance. An ANN model was developed based on the Levenberg-Marquardt algorithm for the engine. Logistic activation was used for mapping between the input and output parameters. It was observed that the ANN model could predict the engine performance quite well with correlation coefficients (R) of $0.996684,0.999,0.98964$ and 0.998923 for the incylinder pressure, heat release, thermal efficiency, and volume, respectively. The predicted MSE (mean square error) error was between the desired outputs, as the measured and simulated values were obtained as 0.0001 by the model. Long-term effects on engine performance when running on biodiesel fuel can be further studied and improved.
\end{abstract}

Keywords: Artificial neural network, biodiesel, engine performance, palm oil methyl ester.

\section{INTRODUCTION}

Fossil fuel and major greenhouse gas and global warming effects have increased due to the dependence of many countries since in Middle East possessing over 55\% of their energy needs [1-7]. The combustion of fossil fuel produces $\mathrm{CO}$ that contributes to major greenhouse gas and global warming effects. Due to the instability of the price of fossil fuel, biofuel has attracted attention due to its attribute of being renewable. Nitrogen oxide from diesel engines is a significant pollutant which requires proper control strategies to mitigate health and environmental impacts [8-13]. Compression ignition (CI) engines are much more fuel-efficient. Although the compression ignition engine is the best choice for fuel economy, there is the problem of nitrogen oxides and particulate matter, as well as the release of polycyclic aromatic hydrocarbons (PAHs), carcinogenic effects and the controlled matter of heavy-duty diesel engines under the US-HDD temporary cycle. In fact, due to the diminishing petroleum reserves and 
environmental pollution caused by the emission of exhaust gases from petroleum engines, alternative fuels are becoming important for diesel engines and have to be developed as soon as possible [14, 15]. Biodiesel has the potential to improve fuel efficiency and decrease the emission of exhaust gases, so many countries in Europe are interested in the evaluation of biodiesel fuels production. Biodiesel is typically defined as an alternative fuel in which vegetable oil uses the reaction of methanol to the presence of a catalyst to produce methyl esters and glycerin [16]. Furthermore, biodiesel has the additional advantage of being biodegradable because it is from plant material, and has the potential to be domestically produced so that demand for petroleum oil can be reduced. Compared with conventional diesel fuel, biodiesel's levels of carbon monoxide, particulate matter (PM), and nitrogen oxides (NOx) in the combustion emission of exhaust gases are reduced and the $\mathrm{CO}_{2}$ level as a greenhouse gas is also decreased [17]. Nowadays, researchers are finding that some alternative fuels can be a countermeasure to unstable oil prices. Alternative fuels include bio petrol, hydro fuel, and biodiesel among the new sources of energy for vehicles. However, these alternative fuels are still undergoing further research before they can be practically used as reliable sources of energy in combustion engines. Crude oil is the most common form of fossil fuel or non-renewable energy found in Malaysia and is in demand in many countries such as Japan, Singapore, South Korea and Thailand. The high quality and low sulfur content are factors in this demand [18].

Despite the active exportation of oil, the government still needs to import a huge amount of crude oil to fulfil local demand. An unstable uncontrolled oil price leads to high government expenditure in the budget, due to the policy of highly subsidized fuel for the local market in the future. Therefore, the Malaysian Palm Oil Board (MPOB) established by the Government has for many years been conducting research on the potential of crude palm oil as an alternative fuel and substitute for the diesel fuel derived from petroleum. The MPOB currently produces a wide range of biodiesel products from animal fats and vegetable oils. Biodiesel products include the famous palm oil-based methyl ester [19] or processed-liquid palm oil (PLPO). It can be blended with diesel in certain percentages or can be used in current diesel engines. Malaysia, as the world's largest manufacturer of palm oil, with 17.7 million tons in 2008 [20] is the largest exporter of biodiesel fuel due to the large stock amount of palm oil. Thus, by using biodiesel, it is able to reduce the dependency on diesel and also benefits the planters with increasing palm oil prices [21-23]. In order to reduce particulate matter and nitrogen oxides and other exhaust gas emissions, the coupled use of biodiesel fuel blends as another fuel can reduce current demand for and shortages of fossil fuel and also help reduce pollution emissions and improve engine performance, yielding more efficient, economical and clean emissions as well. The objectives of this study are to investigate the engine performance using biodiesel in a diesel engine and to develop an optimization model for the engine performance using the artificial neural network technique.

\section{METHODS AND MATERIALS}

The experimental study was carried out on a 4-cycle, 4-cylinder, indirect injection (IDI), water-cooled Mitsubishi 4D68 diesel engine. An eddy-current Dynalec dynamometer, model ECB-200F SR 617 type water-cooled with $150 \mathrm{~kW}$ was used to load the engine. The diesel engine is coupled with the eddy-current dynamometer to load the engine, with a throttle speed sensor to give feedback to control the engine rpm, an air flow and 
fuel flow rate sensor to measure the fuel consumption and a crank encoder sensor with an in-cylinder pressure sensor to determine the pressure and volume in-cylinder according to the engine crank angle. All combustion gases pass through the exhaust manifold. Figure 1 shows the diesel engine test rig which is placed with a pressure transducer, crank angle encoder, and a load cell having several measurement equipments, such as different thermocouples, the eddy-current dynamometer with dynamometer coupling, assisted by different types of hose to connect the air box, air heater and exhaust chamber. The detailed specifications of the engine are shown in Table 1.

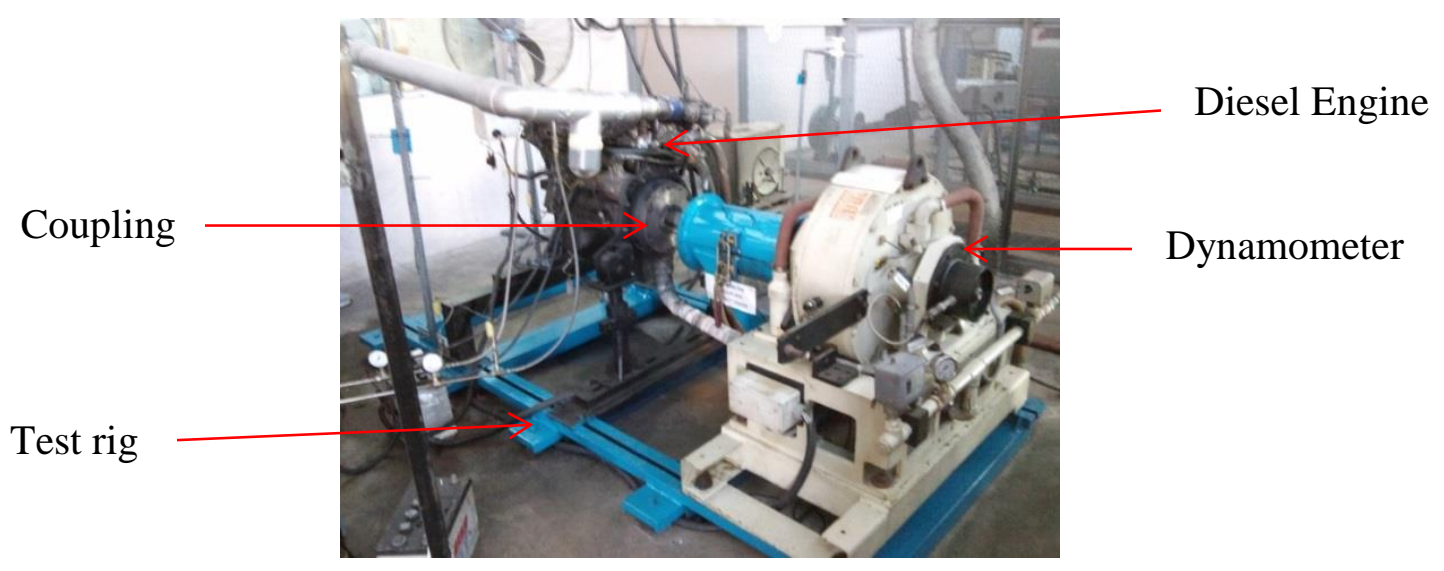

Figure 1. Diesel engine test rig.

Table 1. Diesel engine specifications.

\begin{tabular}{ll}
\hline Description & Specification \\
\hline Manufacturer & Mitsubishi Motors Corporation Japan \\
Type / Model & Diesel / 4D68 \\
Number of cylinders & 4 \\
Combustion chamber & Swirl chamber \\
Total displacement $\left(\mathrm{dm}^{3}\right)$ & 1998 \\
Piston stroke & 82.7 \\
Compression ratio & 22.4 .1 \\
Lubrication system & Pressure feed, full-flow filtration \\
Power & $64.9 \mathrm{~kW}$ @ 4500 rpm \\
Maximum torque & 177 Nm @ 2500 rpm \\
Water pump type & Centrifugal impeller type \\
EGR type & Single type \\
Fuel system & Electronic distributor-type injection pump \\
\hline
\end{tabular}

After connecting the diesel engine with the dynamometer by a drive shaft couple, throttle actuators integrated with the engine control the engine speed. This is operated by a servo motor to turn the throttle actuator, depending on the experiment requirement. The dynamometer has a load cell control provided by a Dynalec ECB$200 \mathrm{~F} 150 \mathrm{~kW}$. The torque measurement can be obtained by the Dynalec dynamometer with the load cell controller shown in Figure 2. This dynamometer can absorb a maximum power rating of $150 \mathrm{~kW}(2500-13000 \mathrm{rpm})$ and is able to measure the torque rating up to $60 \mathrm{kN}(1500-2500 \mathrm{rpm})$. The load cell is the strain gauge, where the force is 
exerted from the rotation of the dynamometer arm and analog input manipulated by the computer to the engine brake power value. The kinematic viscosity is also an important property that has to be considered to ensure better engine performance. The testing utilized ASTM standards in which the procedure testing temperature was $40^{\circ} \mathrm{C}$ on the standard viscosity measurement equipment shown in Figure 3.

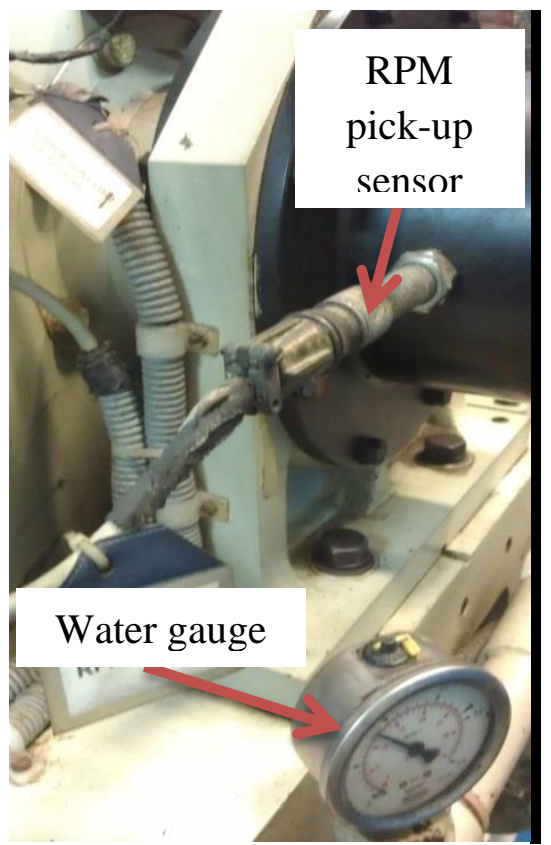

(a)

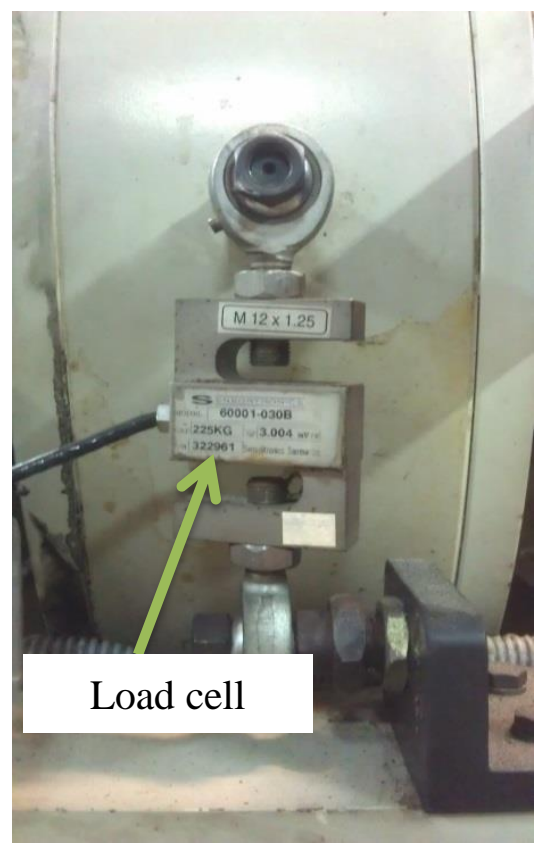

(b)

Figure 2. (a) Engine speed sensor and (b) load cell sensor.

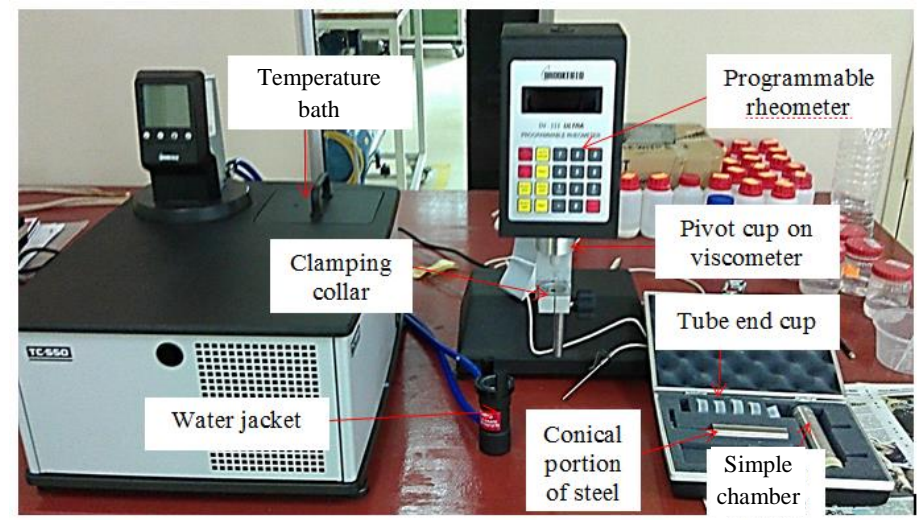

Figure 3. Viscosity measurement setup.

In order to develop an artificial neural network (ANN) model to get the best prediction results, several architectures were estimated and trained using the experiment data. Firstly, a back-propagation algorithm was utilized for testing, training and validation processes. This algorithm is used to supervise the training technique, where the weight and biases of training networks are set randomly at the start of the training stage. A gradient descent rule for the minimization process of error is achieved. In the network architecture, there are two input and four output parameters in the experimental data evaluation. The two input variables are the engine crank angle in degrees and the 
engine speed in rpm with the conventional diesel engine. The four output parameters include the pressure in-cylinder in bar, heat release in percentage, thermal efficiency in percentage and volume generated in $\mathrm{dm}^{3}$. Thus, the two input variables at the input layer consist of two neurons related to the crank angle of the diesel engine and its engine speed. Figure 4 shows the architecture of the ANN model for the prediction of engine performance using biodiesel as fuel.

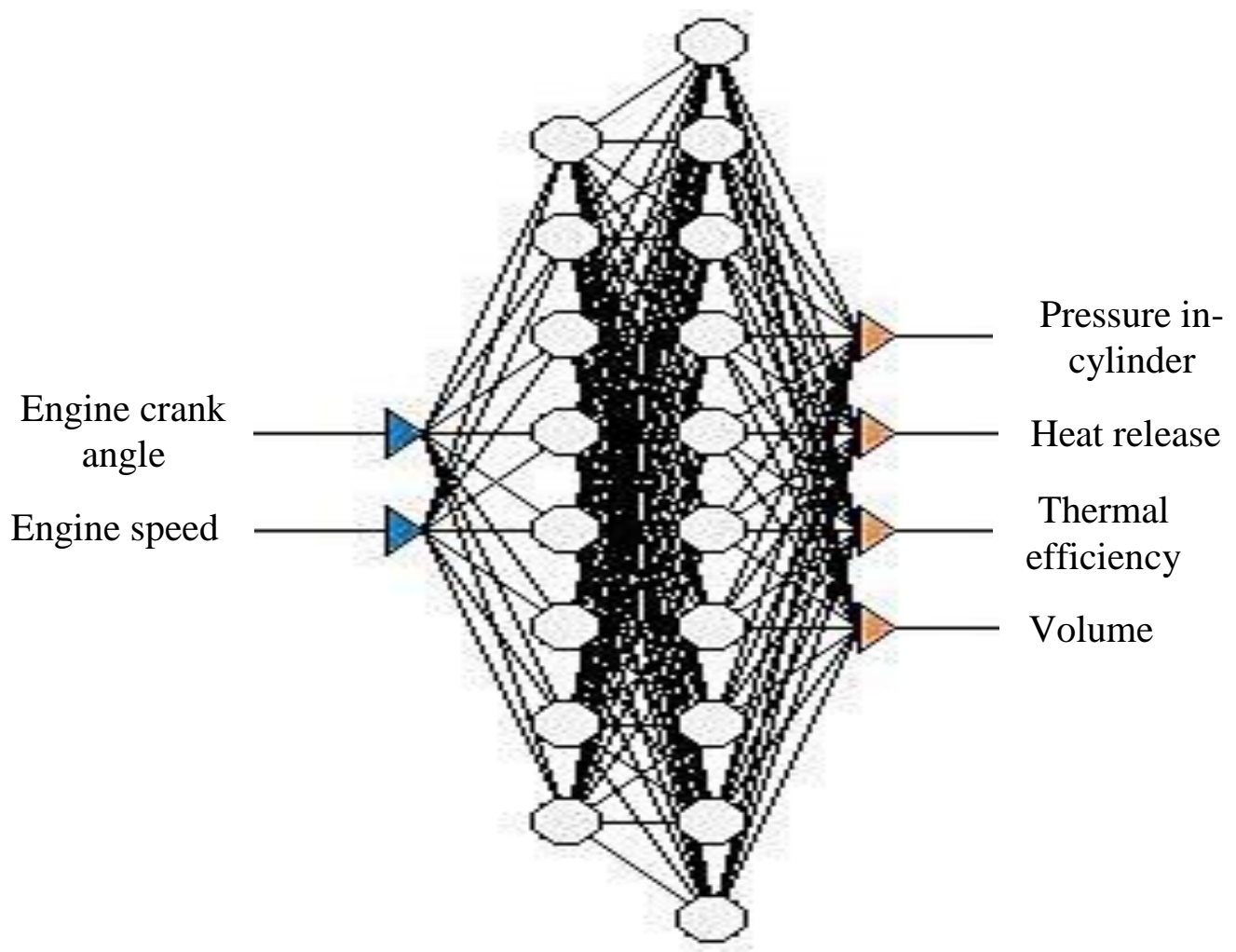

Figure 4. Architecture of artificial neural network.

Table 2. Summary of network evaluated.

\begin{tabular}{lclcc}
\hline Name & Architecture & $\begin{array}{l}\text { Training } \\
\text { algorithm }\end{array}$ & $\begin{array}{c}\text { Avg training } \\
\text { error }\end{array}$ & Avg test error \\
\hline Network 1 & $2-2-3-4$ & $\begin{array}{l}\text { Quick } \\
\text { Propagation } \\
\text { Conjugate } \\
\text { Gradient } \\
\text { Detwork 2 }\end{array}$ & 0.007896 & 0.008176 \\
2-4-3-4 & $\begin{array}{l}\text { Q } \\
\text { Quasi-Nent } \\
\text { Network 3 }\end{array}$ & $2-5-3-4$ & 0.04778 & 0.004887 \\
Network 4 & $2-6-5-4$ & $\begin{array}{l}\text { Limited } \\
\text { Memory Quasi- }\end{array}$ & 0.004399 & 0.004532 \\
Network 5 & $2-8-10-4$ & $\begin{array}{l}\text { Newton } \\
\text { Levenberg- } \\
\text { Marquardt } \\
\text { Batch Back } \\
\text { Propagation }\end{array}$ & 0.004199 & 0.004224 \\
Network 6 & $2-7-5-4$ & 0.004473 & 0.004557 \\
\hline
\end{tabular}


The complexity of the problem and experimental data set can be designed based on the number of neurons and hidden layers in each layer. In this project, two hidden layers were used to make sure that the input variables make an equal contribution in the ANN models. The logistic activation function was selected for the hidden layer activation and the same was applied at the output layers. Furthermore, for the training and testing performance the mean squared error (MSE) set at 0.0001 was preferred for all ANN models. Finally, an R-squared and correlation analysis between the neuron network response and related targets was performed in order to investigate the network response in more detail. Table 2 shows a summary of the network evaluated. After different training algorithms were tested, the Levenberg-Marquardt training algorithm was selected.

\section{RESULTS AND DISCUSSION}

Three different blends, B5, B10 and B20, are used in this study. The blend properties are summarized in Table 3. B5 is the standard benchmark used in the experiment. It can be observed that the density, kinematic viscosity, flash point and cetane number increase with increase of the POME mixture, indicating the increase of the blend mixtures. However the heating values decrease with increase of the POME mixture. Thus, it can be observed that B10 can be more powerful and fuel-efficient, having the best cetane number and heating value.

Table 3. Fuel properties.

\begin{tabular}{lcccc}
\hline Fuel properties & B5 & B10 & B20 & Diesel Fuel \\
\hline Heating value $(\mathrm{MJ} / \mathrm{kg})$ & 48.1392 & 46.783 & 46.6585 & 45.2 \\
Density $\left(\mathrm{kg} / \mathrm{m}^{3}\right)$ & 835 & 837 & 843 & 820 \\
Kinematic viscosity $\left(\mathrm{cst} @ 40^{\circ} \mathrm{C}\right)$ & 3.67 & 3.73 & 3.85 & 3.05 \\
Cetane number & 48.1 & 55.1 & 51.6 & 47 \\
Flash point $\left({ }^{\circ} \mathrm{C}\right)$ & 116 & 108 & 118 & 80 \\
\hline
\end{tabular}

Figure 4(a) presents the variation of torque with engine loading and fuel blends. It is observed that the torque increases with increase of engine loading. However, there is no noticeable difference between the fuel blends. However, for other blends the measured engine torque is lower than that of B5 fuel. The torque delivered with B5 fuel was higher on average than the torque delivered by B10 and B20 at $20 \%$ of engine load. Figure 4(b) shows the brake power against biodiesel blends and engine loading. The engine was running at a constant speed of $2500 \mathrm{rpm}$. As can be seen, B5 produces more power than B10 and B20 at 20\% of engine load. It is observed that engine power increases with increase of engine loading. However, there are no noticeable differences of engine power between the fuel blends. Figure 4(c) represents brake specific fuel consumption (BSFC) versus engine load among the biodiesel blends. When the engine is $20 \%$ loaded, it is observed that B5 has the best BSFC due to having a higher heating value compared to B10 and B20. Besides, B5 also has low density and kinematic viscosity fuel properties, which contribute to lower fuel consumption, and even to maintaining brake power at a constant speed. Although B5 is the best BSFC, at $40 \%$ of engine load it is observed that all the biodiesel blends are the same. Furthermore, B10 at $60 \%$ engine load is the lowest compared with B5 and B20. Even though increased POME in the blends leads to high density, kinematic viscosity and flash point, the 
properties of the biodiesel fuel, including lubricity and high oxygen content could be protecting the engine, with smoother running and generating more energy for the diesel engines in terms of BSFC [24]. Figure 4(d) shows the brake thermal efficiency (BTE) versus engine load of the various biodiesel blends. It can be seen that at $20 \%$ engine load, the highest BTE is B5, which is $9.6 \%$ higher than B10 and $16.1 \%$ higher than B20. It is defined that the engine's conversion to thermal energy from the heating value of fuel can affect the thermal efficiency. The heating value from B5 is the highest, which is $0.96 \%$ and $1.05 \%$ higher than B10 and B20 respectively. The graph also shows that at $40 \%$ engine load the thermal efficiency of B5, B10 and B20 is the same. But when the engine load is increased to $60 \%, \mathrm{~B} 10$ produced higher thermal efficiency than B5 and B20, being 3.7\% higher than B5 and 15.1\% higher than B20.

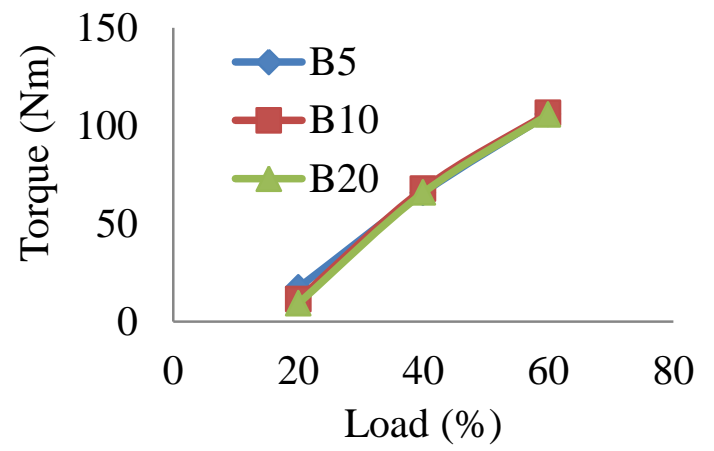

(a) Torque

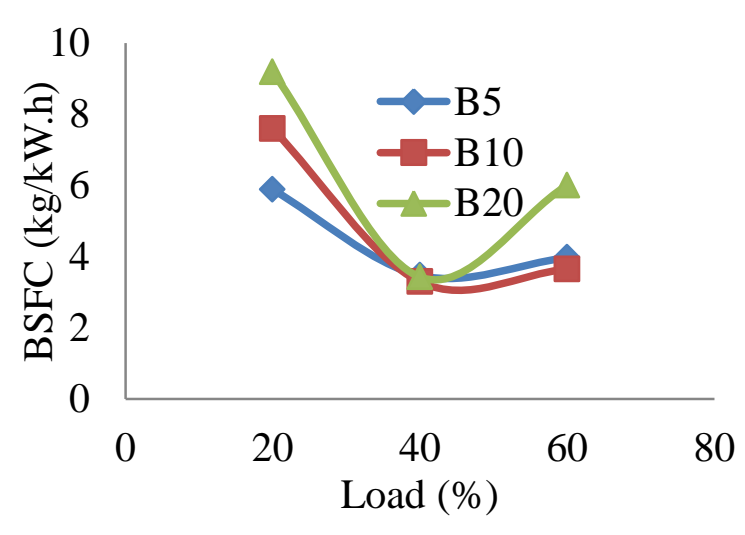

(c) Brake specific fuel consumption

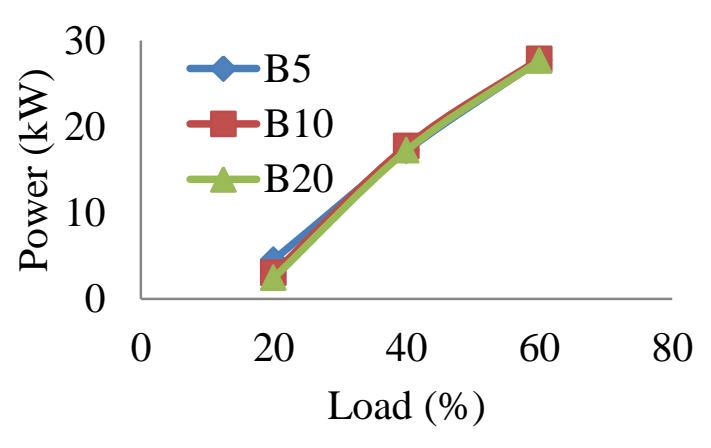

(b) Engine brake power

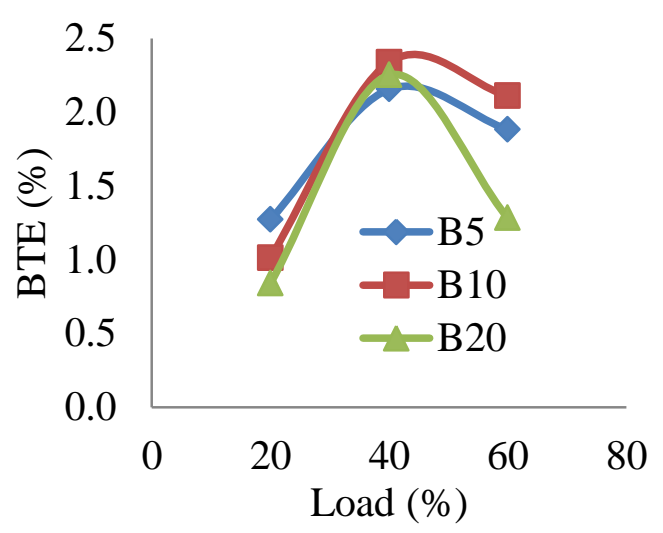

(d) Brake thermal efficiency

Figure 4. Comparison between the engine performance of biodiesel blends.

Figure 5 presents the variation of brake mean effective pressure (BMEP) against engine loading conditions. It can be observed that BMEP increases with increase of engine load and there is no significant variation among the mixture blends (B5, B10 and B20) at the $60 \%$ engine loading condition. Unfortunately, at $20 \%$ engine loading it is observed that BMEP decreases among the blend mixtures, where B5 is 20.32 bar, B10 is 18.03 bar and lastly B20 is 14.67 bar. A similar result was reported by [25], who compared diesel and sunflower biodiesel blend, where a 5-10\% power reduction was due to the lower heating value of the biodiesel fuel. 


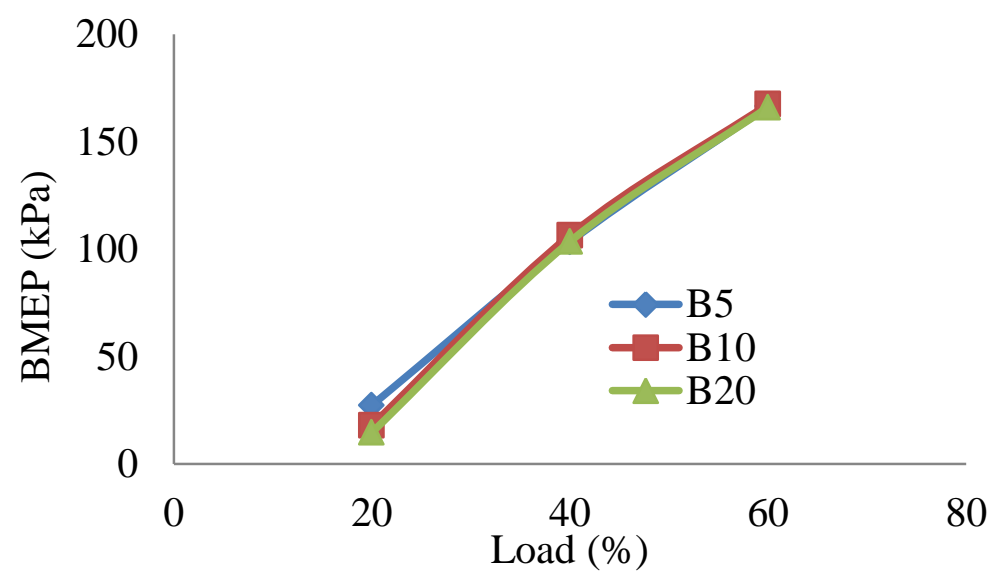

Figure 5. Variation of pressure with engine load.

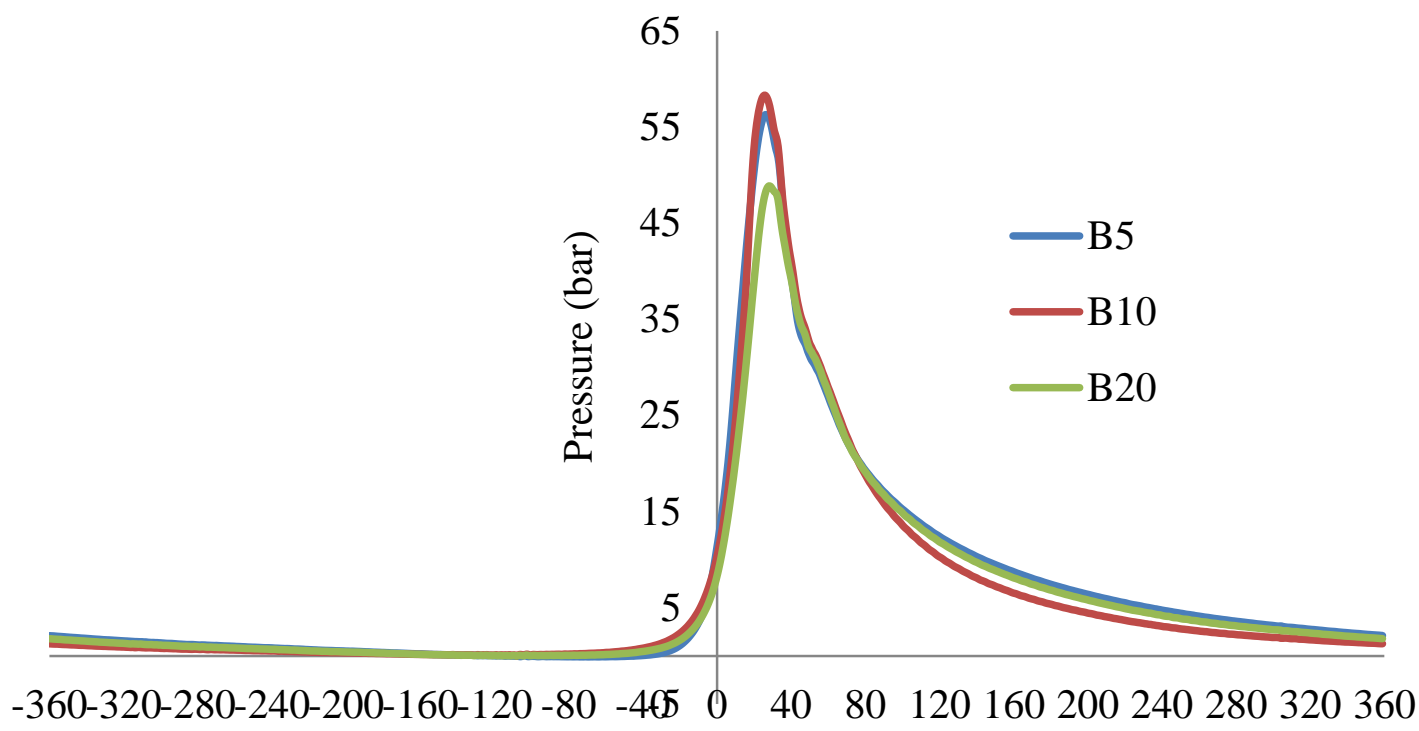

Crank angle $\left({ }^{\circ} \mathrm{CA}\right)$

Figure 6. Variation of in-cylinder pressure versus crank angle (degrees).

Figure 6 presents the in-cylinder pressure against crank angle in degrees for various fuel blends. It can be observed that B10 achieved the highest pressure compared to the others at an engine speed of $2500 \mathrm{rpm}$ and crank angle of $26^{\circ}$. The lack of atomization of the biodiesel fuel injection spray in B20 can decrease the combustion pressure. The higher the density and kinematic viscosity produced, the harder it is for the fuel to be converted to spray in the combustion chamber of a diesel engine. The same result was found when comparing pure waste-oil biodiesel and diesel fuel, where the reported torque loss was about $3 \%$ to $5 \%$ with the biodiesel fuels. This is because the higher viscosity of biodiesel affected the power and engine brake effective power due to the surface tension of biodiesel, which prevents sufficient atom vaporization during the injection process [26]. B10 achieved the highest pressure due to the high oxygen content in the biodiesel molecules, bringing an increased rate of combustion, peak temperature and pressure. The short ignition delay period, high cetane number and high viscosity lead the biodiesel to the maximum position of peak pressure towards the top dead center (TDC) after a short period of expansion stroke [27]. 
Figure 7 shows that heat release occurred starting at the crank angle of $-90^{\circ}$ and reached the optimum $100 \%$ of heat release at the $90^{\circ}$ engine crank angle. It can be observed that the B10 heat release line trend suddenly increased compared with B5 and B20. B5 and B20 have similar heat release results occurring after the combustion phase. The heat release can affect aspects of the engine performance such as pressure incylinder and thermal efficiency, as it is proportional to both thermal efficiency and incylinder pressure. The heat release can produce more heat, affecting the pressure incylinder when combustion occurs, and this could generate more torque and thus produce more powerful brake power in the diesel engine. Similar conclusions were reached by [28], that heat release from crude sunflower-oil is higher than with diesel fuels because combustion of the diesel fuel started earlier than crude sunflower-oil and the diesel fuels produced a shorter ignition delay period.

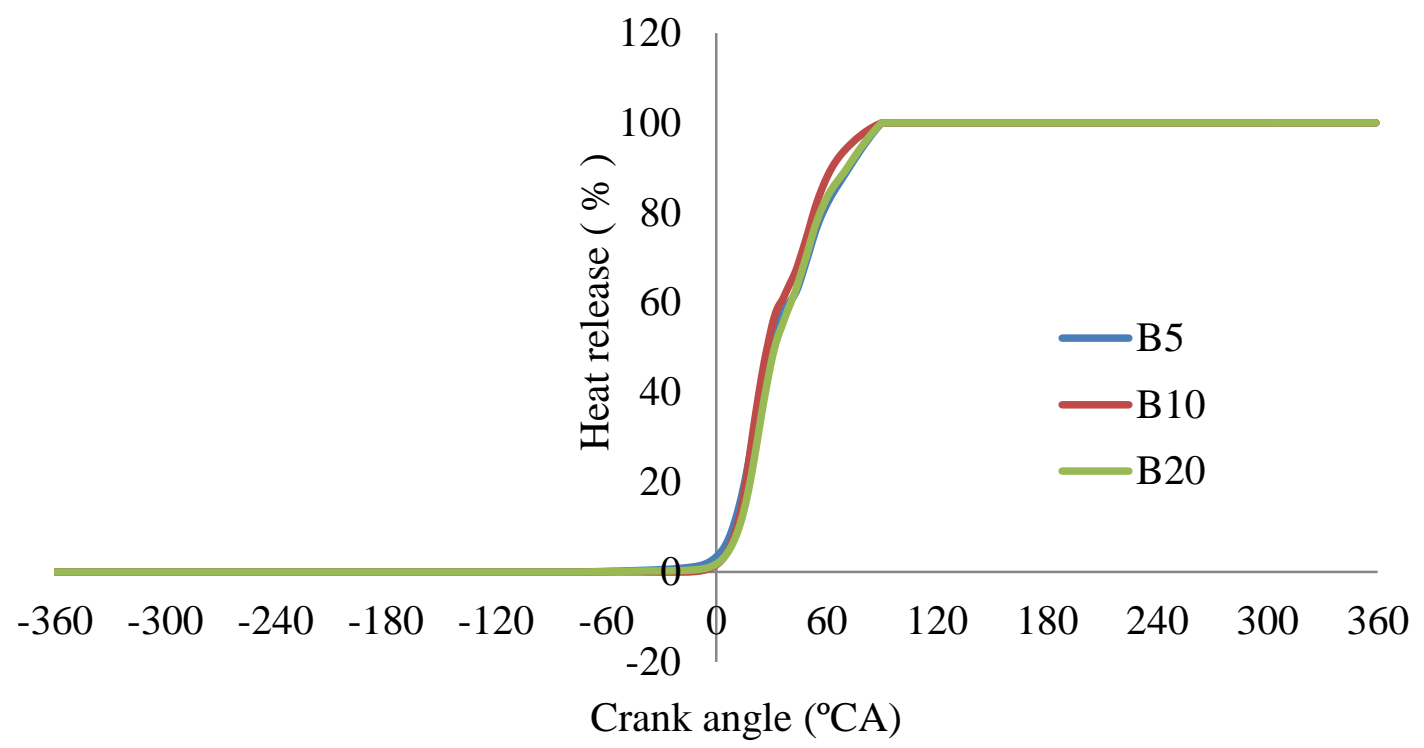

Figure 7. Variation of heat release versus crank angle (degrees).

Figure 8 shows that B10 has higher thermal efficiency than B5 and B20. At an engine load of $40 \%$ with $2500 \mathrm{rpm}$ in constant speed, the heat release from B10 is the highest compared to B5 and B20. Thus, thermal efficiency over crank angle for B10 can give the optimum biodiesel fuel performance. When comparing the fuel consumption, it can be proved that the higher the thermal efficiency of the biodiesel generated, the higher the fuel consumption efficiency. Even though B10 has moderate values of density, kinematic viscosity and heating, the experiment shows that B10 is the optimum fuel compared to the other biodiesels. According to [24], the improvement in brake thermal efficiency was obtained by the increasing content of biodiesel fuel with the $10 \%$ and $20 \%$ blends. This is because increasing the biodiesel content also increases the lubricity contained in biodiesel. 


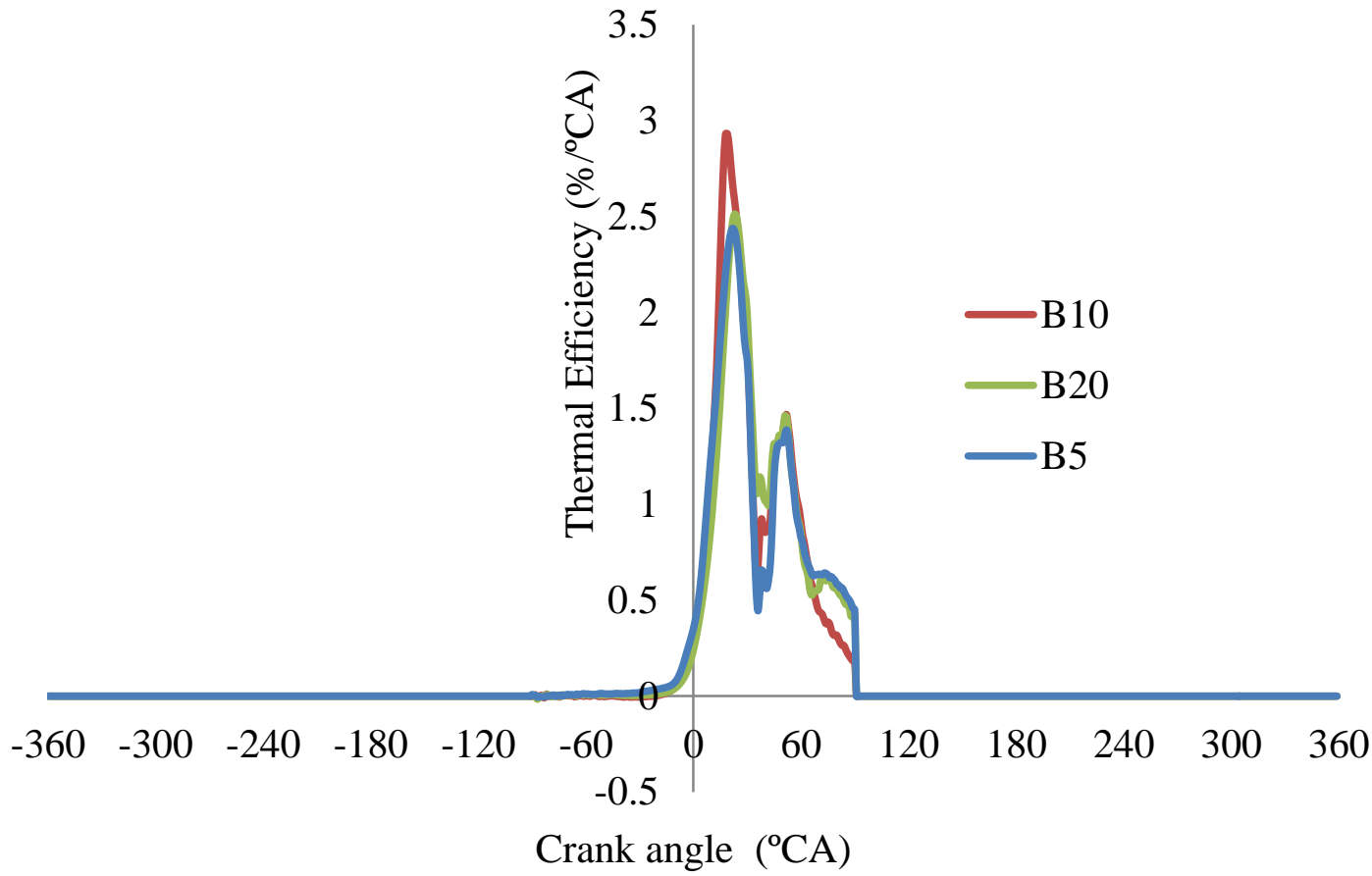

Figure 8. Variation of thermal efficiency versus crank angle (degrees).

Table 4. Error analysis of pressure in-cylinder and thermal efficiency for the network.

\begin{tabular}{|c|c|c|c|c|}
\hline \multicolumn{5}{|l|}{ Best Network } \\
\hline \multicolumn{5}{|c|}{ (a) } \\
\hline Iteration & \multicolumn{2}{|c|}{68} & & \\
\hline Network error & \multicolumn{3}{|c|}{0.000268} & \\
\hline Error improvement & \multicolumn{3}{|c|}{$9.74 \times 10^{-9}$} & \\
\hline \multicolumn{5}{|c|}{ (b) } \\
\hline Pressure in-cylinder & Target & Output & $\mathrm{AE}$ & ARE \\
\hline Mean & 4.729599 & 4.733764 & 0.271206 & 0.473278 \\
\hline Std dev & 7.817052 & 7.740119 & 0.28072 & 10.04117 \\
\hline Min & -0.05744 & 0.192107 & 0.000037 & 0.000018 \\
\hline Max & 45.80025 & 42.94433 & 3.282978 & 1007.13 \\
\hline Correlation & 0.999949 & & & \\
\hline R-squared & 0.999894 & & & \\
\hline \multicolumn{5}{|c|}{ (c) } \\
\hline Thermal efficiency & Target & Output & $\mathrm{AE}$ & $\mathrm{ARE}$ \\
\hline Mean & 0.072676 & 0.045581 & 0.040116 & $5.31 \times 10^{-16}$ \\
\hline Std dev & 0.253665 & 0.259151 & 0.030342 & $4.06 \times 10^{-16}$ \\
\hline Min & -0.05289 & -0.05289 & 0.00001 & 0.000514 \\
\hline Max & 1.714909 & 1.614221 & 0.516145 & $2.04 \times 10^{-16}$ \\
\hline Correlation & 0.98657 & & & \\
\hline R-squared & 0.96233 & & & \\
\hline
\end{tabular}


The ANN was tested against output data for pressure in-cylinder and thermal efficiency and results utilized the Levenberg-Marquardt training algorithm, which was evaluated against about 18 cycles of the diesel engine. After 68 iterations, the network error between the target and output is 0.000268 and the training is stopped. Table 4(a) represents the error analysis between the target and output of the ANN models. The error of output generated using the ANN in terms of pressure in-cylinder and thermal efficiency is shown in Table 4(b) and (c). It is observed that the accuracy of the pressure in-cylinder and thermal efficiency is $99.9894 \%$ and $96.233 \%$ respectively. In order to make sure that the target and output are acceptable, Figure 9 shows the scatter plot between the pressure in-cylinder and thermal efficiency respectively. It can be seen that it is mostly scattered near the perfect correlation line for both pressure in-cylinder and thermal efficiency.

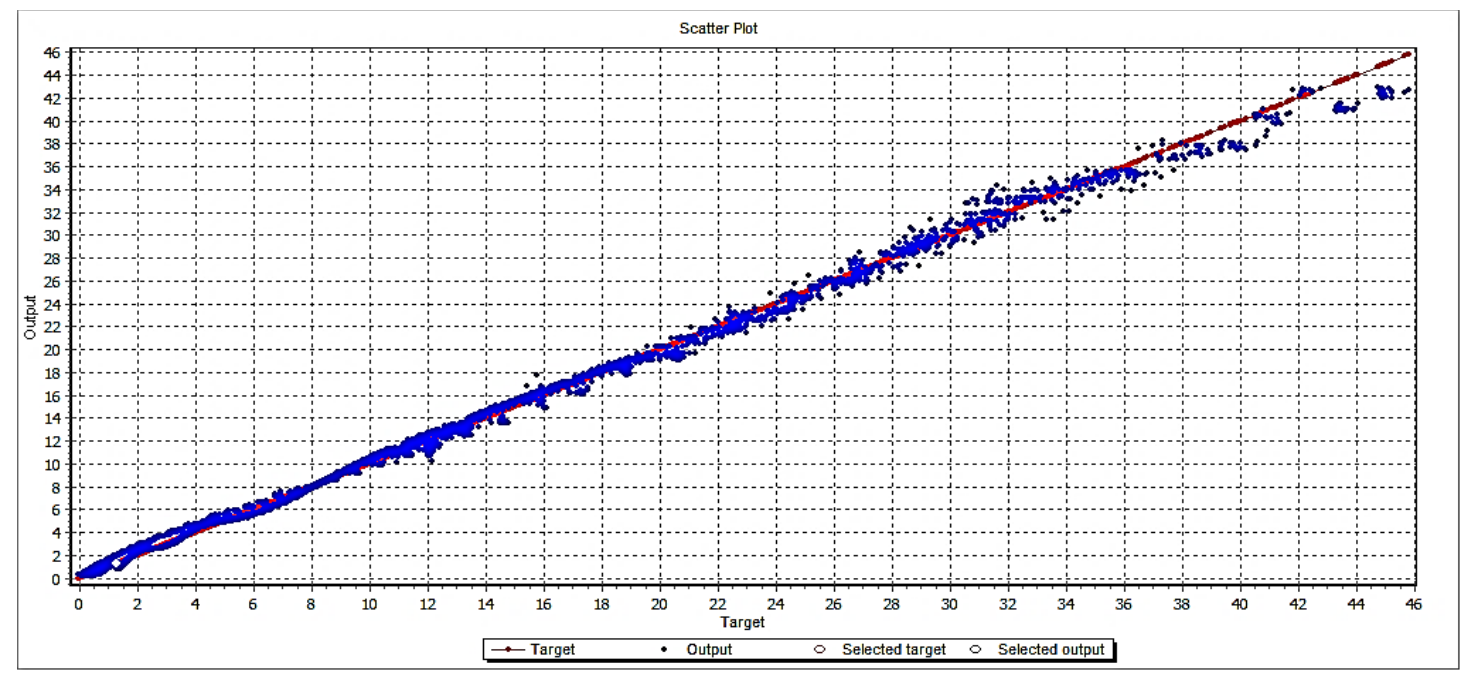

(a)

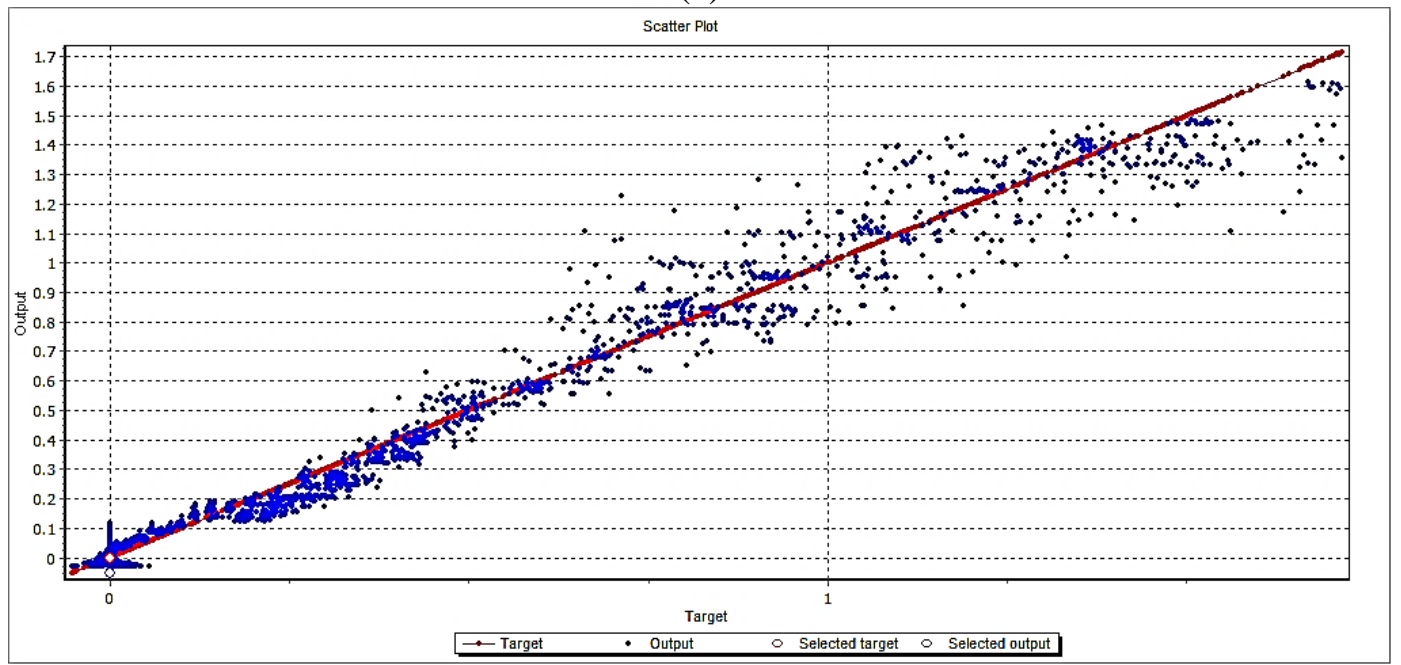

(b)

Figure 9. Scatter plot

In Figure 10(a), the prediction using ANN models shows that the highest pressure obtained by the experimental data is 45.28 bar and the lowest is 39.27 bar for predicted data. Both the experimental and predicted data were run at $2500 \mathrm{rpm}$ engine speed. It can be concluded that the ANN models can predict different engine speeds 
according to the crank angle of the diesel engine. Figure 10(b) represents the variation of the thermal efficiency against the crank angle in degrees. From comparison of the experimental and predicted data, good correlation is observed throughout the cycle. The highest thermal efficiency is obtained for predicted results, which are about $2.91 \%$ higher than the experimental results.

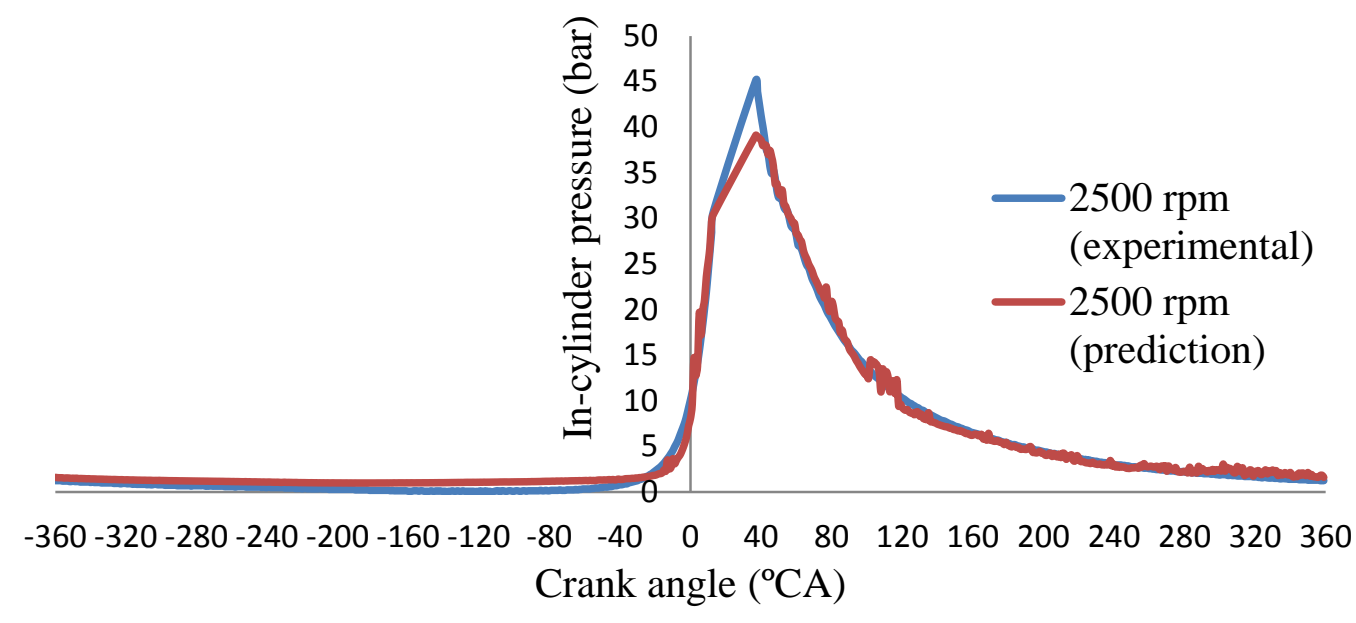

(a) In-cylinder pressure

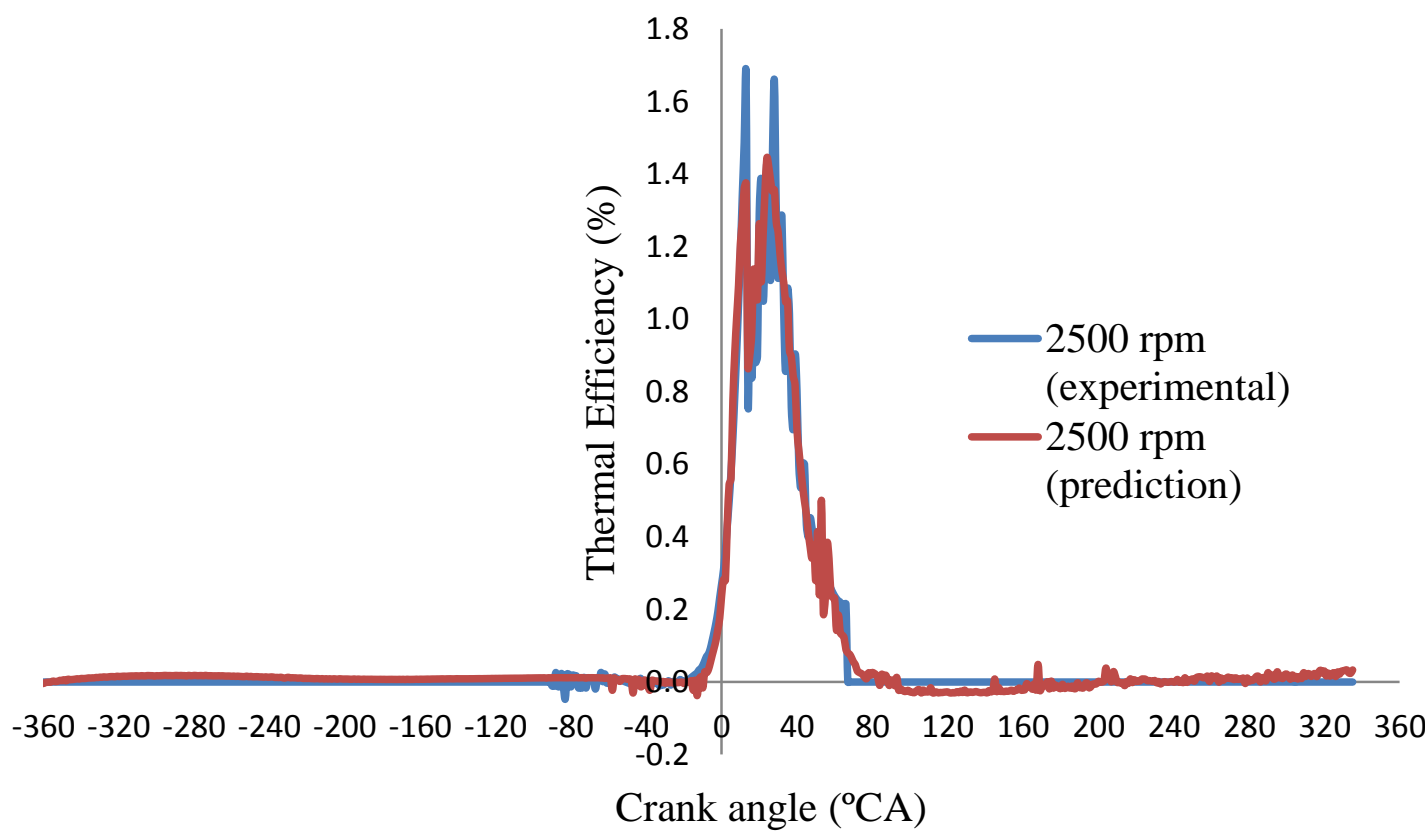

(b) Thermal efficiency

Figure 10. Comparison between prediction and experimental data for in-cylinder pressure and thermal efficiency.

Comparison between the experimental data and the ANN predicted results showed slight differences in values. Figure 11 shows the scatter plot of pressure incylinder and thermal efficiency between the predicted and experimental results. It can be seen that the scattered results are well distributed. The experimental results and the 
results predicted by ANN are mostly almost the same. Thus, it can be concluded that the network can be utilized for engine performance evaluation. The engine performance conditions used in the confirmation test for in-cylinder pressure and thermal efficiency are presented in Tables 5 and 6, respectively. It is observed that the errors predicted for in-cylinder pressure and thermal efficiency are below 5\%, which is an acceptable result.

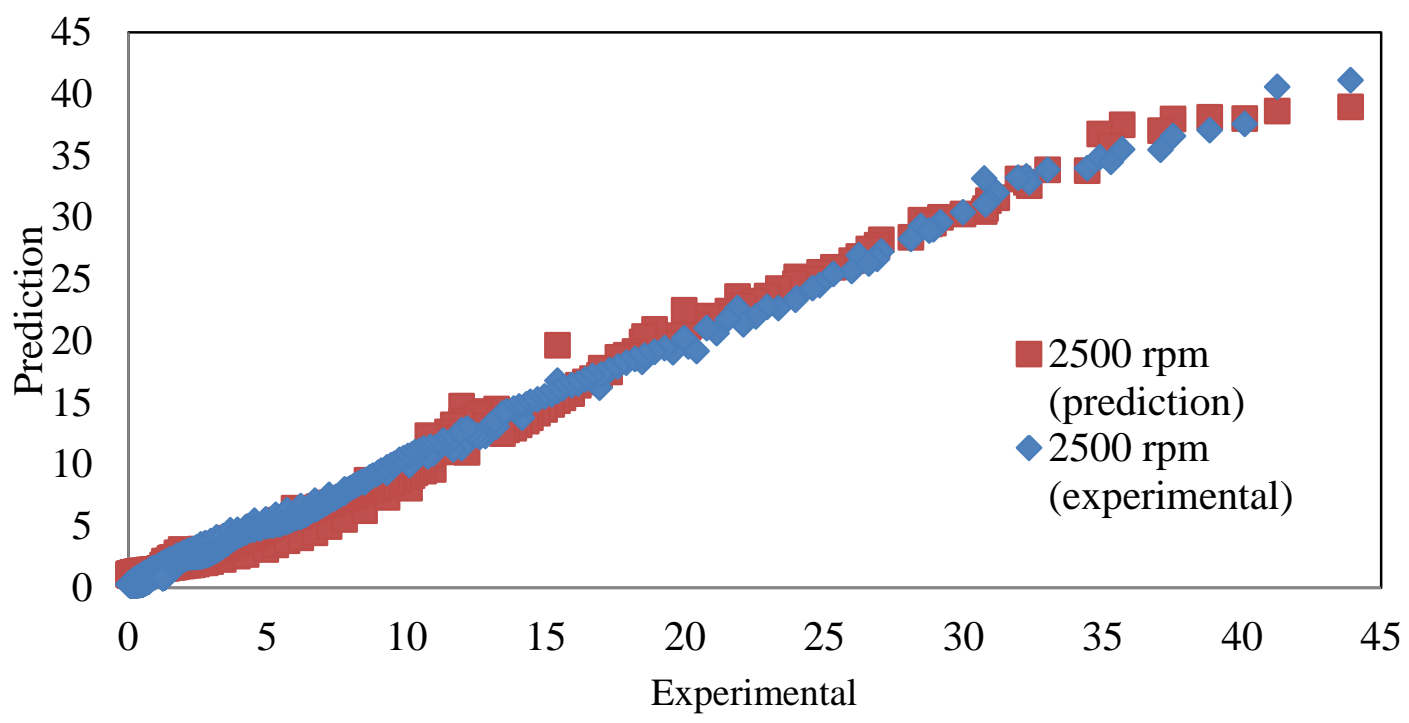

(a) In-cylinder pressure

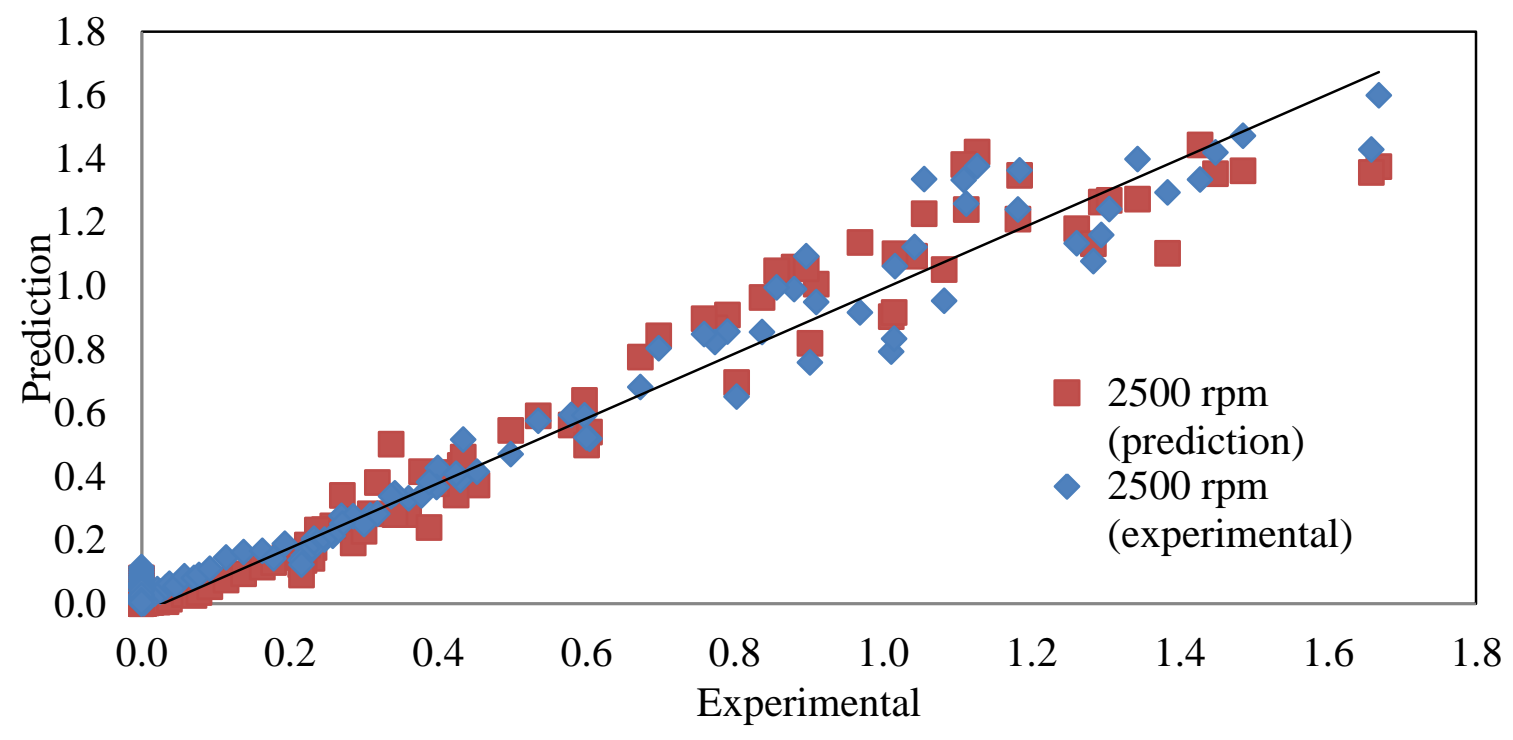

(b) Thermal efficiency

Figure 11. Scatter plot comparison of prediction data and experimental data for pressure in-cylinder and thermal efficiency 
Table 5. Error for ANN predicted results compared with experiment for in-cylinder pressure.

\begin{tabular}{cccc}
\hline $\begin{array}{c}\text { Crank angle } \\
\left({ }^{\mathrm{c}} \mathrm{ca}\right)\end{array}$ & $\begin{array}{c}\text { Experimental } \\
\text { in-cylinder pressure } \\
(\text { bar })\end{array}$ & $\begin{array}{c}\text { Predicted } \\
\text { in-cylinder pressure } \\
(\text { bar })\end{array}$ & Error \\
\hline-360 & 0.835469 & 0.869034 & 3.3565 \\
-359 & 0.816951 & 0.862892 & 4.5941 \\
-358 & 0.809783 & 0.856819 & 4.7036 \\
-357 & 0.808251 & 0.850815 & 4.2564 \\
-356 & 0.806345 & 0.844882 & 3.8537 \\
& & Average error & 4.1529 \\
\hline
\end{tabular}

Table 6. Error for ANN predicted results compared with experiment for thermal efficiency.

\begin{tabular}{cccc}
\hline $\begin{array}{c}\text { Crank angle } \\
\left({ }^{\mathrm{o}} \mathrm{ca}\right)\end{array}$ & $\begin{array}{c}\text { Experimental } \\
\text { thermal efficiency } \\
\left(\% /{ }^{\circ} \mathrm{ca}\right)\end{array}$ & $\begin{array}{c}\text { Predicted } \\
\text { thermal efficiency } \\
\left(\% /{ }^{\circ} \mathrm{ca}\right)\end{array}$ & Error \\
\hline-360 & $5.45 \times 10^{-19}$ & 0.013735 & 1.37 \\
-359 & $5.45 \times 10^{-19}$ & 0.009425 & 0.943 \\
-358 & $5.45 \times 10^{-19}$ & 0.008811 & 0.881 \\
-357 & $5.45 \times 10^{-19}$ & 0.010118 & 1.01 \\
-356 & $5.45 \times 10^{-19}$ & 0.011219 & 1.12 \\
& & Average error & 1.07 \\
\hline
\end{tabular}

\section{CONCLUSIONS}

The performance of a diesel engine fuelled with POME was experimentally investigated. Engine tests were done for 5\%, 10\% and 20\% blends with diesel fuel. The experimental results revealed that blends of palm oil methyl ester with diesel fuel provide the same engine performance as other biodiesel blends such as B5 (5\% POME and $90 \%$ diesel fuel). This means that for further production of biodiesel for use in conventional diesel engines, the increasing percentage of POME blends with diesel fuel can proceed with B10 (10\% POME and 90\% diesel). B10 gives the best engine brake thermal efficiency. It has no positive effect on the BSFC of the engine. It can be observed that the density, kinematic viscosity, flash point and cetane number increase with increase of the POME in the mixture, i.e. with increase of the blend mixture. However, the heating values decrease with increase of the POME mixture. Thus, it is can be observed that B10 can be more powerful and fuel-efficient due to having the best cetane number and heating value. It was observed that the ANN models can predict the engine performance quite well, with correlation coefficients (R) of 0.999894 and 0.96233 for the in-cylinder pressure and thermal efficiency, respectively. The prediction MSE (Mean Square Error) error was between the desired outputs, as the measured and simulated values were obtained as 0.0001 by the model. 


\section{ACKNOWLEDGEMENTS}

The authors would like to acknowledgements Ministry of Education Malaysia and Universiti Malaysia Pahang for providing laboratory facilities and financial support under project no. RDU1403126 and Graduate Research Scheme No GRS140381 .

\section{REFERENCES}

[1] Escobar JC, Lora ES, Venturini OJ, Yáñez EE, Castillo EF, Almazan O. Biofuels: environment, technology and food security. Renewable and Sustainable Energy Reviews. 2009;13:1275-87.

[2] Kapilan N, Ashok Babu TP, Reddy RP. Improvement of performance of dual fuel engine operated at part load. International Journal of Automotive and Mechanical Engineering. 2010;2:200-10.

[3] Sulaiman SA, Murad SHM, Ibrahim I, Abdul Karim ZA. Study of flow in airintake system for a single-cylinder go-kart engine. International Journal of Automotive and Mechanical Engineering. 2010;1:91-118.

[4] Kamil M, Rahman MM, Bakar RA. Integrated simulation model for composition and properties of gases in hydrogen fueled engine. International Journal of Automotive and Mechanical Engineering. 2013;8:1242-155.

[5] Kamil M, Rahman MM, Bakar RA. An integrated model for predicting engine friction losses in internal combustion engines. International Journal of Automotive and Mechanical Engineering. 2014;9:1695-708.

[6] Nayak C, Pattanaik BP, Nayak SK. Effect of preheated jatropha oil and jatropha oil methyl ester with producer gas on diesel engine performance. International Journal of Automotive and Mechanical Engineering. 2014;9:1709-22.

[7] Vashist D, Ahmad M. Statistical Analysis of Diesel Engine Performance for Castor and Jatropha Biodiesel-Blended Fuel. International Journal of Automotive and Mechanical Engineering. 2014;10:2155-69.

[8] Sawyer CN, McCarty PL, Parkin GF. Chemistry for environmental engineering: McGraw-Hill New York; 1994.

[9] Azad AK, Ameer Uddin SM, Alam MM. A comprehensive study of DI diesel engine performance with vegetable oil: an alternative boi-fuel source of energy. International Journal of Automotive and Mechanical Engineering. 2012;5:57686.

[10] Yusaf T, Hamawand I, Baker P, Najafi G. The effect of methanol-diesel blended ratio on CI engine performance. International Journal of Automotive and Mechanical Engineering. 2013;8:1385-95.

[11] Rahim R, Mamat R, Taib MY, Abdullah AA. Influence of fuel temperature on a diesel engine performance operating with biodiesel blended. Journal of Mechanical Engineering and Sciences. 2012;2:226-36.

[12] Ghobadian B, Najafi G, Nayebi M. A semi-empirical model to predict diesel engine combustion parameters. Journal of Mechanical Engineering and Sciences. 2013;4:373-82.

[13] Abdullah NR, Shahruddin NS, Mamat R, Ihsan Mamat AM, Zulkifli A. Effects of air intake pressure on the engine performance, fuel economy and exhaust emissions of a small gasoline engine. Journal of Mechanical Engineering and Sciences. 2014;6:949-58. 
[14] Ghobadian B, Rahimi H, Nikbakht A, Najafi G, Yusaf T. Diesel engine performance and exhaust emission analysis using waste cooking biodiesel fuel with an artificial neural network. Renewable Energy. 2009;34:976-82.

[15] Fukuda H, Kondo A, Noda H. Biodiesel fuel production by transesterification of oils. Journal of Bioscience and Bioengineering. 2001;92:405-16.

[16] Lee SW, Herage T, Young B. Emission reduction potential from the combustion of soy methyl ester fuel blended with petroleum distillate fuel. Fuel. 2004;83:1607-13.

[17] Elawad M, Yusaf T. Performance and exhaust emission of a diesel engine using crude palm oil as a fuel extender. Journal of Energy \& Environment. 2004;3:618.

[18] Sumathi S, Chai S, Mohamed A. Utilization of oil palm as a source of renewable energy in Malaysia. Renewable and Sustainable Energy Reviews. 2008;12:240421.

[19] Pomeroy CA. Science watch-biogas breakthrough. The Japan Journal. 2008.

[20] Basiron Y. Palm oil production through sustainable plantations. European Journal of Lipid Science and Technology. 2007;109:289-95.

[21] Abdullah AZ, Salamatinia B, Mootabadi H, Bhatia S. Current status and policies on biodiesel industry in Malaysia as the world's leading producer of palm oil. Energy Policy. 2009;37:5440-8.

[22] Hairuddin AA, Wandel AP, Yusaf T. An Introduction to a Homogeneous Charge Compression Ignition Engine. Journal of Mechanical Engineering and Sciences. 2014;7:1042-52.

[23] Yusop AF, Mamat R, Mat Yasin MH, Ali OM. Effects of particulate matter emissions of diesel engine using diesel-methanol blends. Journal of Mechanical Engineering and Sciences. 2014;6:959-67.

[24] Ramadhas A, Muraleedharan C, Jayaraj S. Performance and emission evaluation of a diesel engine fueled with methyl esters of rubber seed oil. Renewable Energy. 2005;30:1789-800.

[25] Kaplan C, Arslan R, Sürmen A. Performance characteristics of sunflower methyl esters as biodiesel. Energy Sources. 2006;28:751-5.

[26] Çetinkaya M, Ulusoy Y, Tekìn Y, Karaosmanoğlu F. Engine and winter road test performances of used cooking oil originated biodiesel. Energy Conversion and Management. 2005;46:1279-91.

[27] Shehata MS. Emissions, performance and cylinder pressure of diesel engine fuelled by biodiesel fuel. Fuel. 2013;112:513-22.

[28] Canakci M, Ozsezen AN, Turkcan A. Combustion analysis of preheated crude sunflower oil in an IDI diesel engine. Biomass and Bioenergy. 2009;33:760-7. 